\title{
Impact of Non-Performing Loans on Bank's Profitability: Empirical Evidence from Commercial Banks in Tanzania
}

\author{
Peter Stephen Kingu ${ }^{1}$, Dr Salvio Macha² , Dr Raphael Gwahula. ${ }^{3}$ \\ ${ }^{1} \mathrm{PhD}$ Student at The Open University of Tanzania, Faculty of Business and Management \\ ${ }^{2}$ Lecturer at The Open University of Tanzania, Faculty of Business and Management \\ ${ }^{3}$ Lecture at The Open University of Tanzania, Faculty of Business and Management
}

\begin{abstract}
:
This study examined the impact of Non-performing loans on bank's profitability using information asymmetry theory and bad management hypothesis. This study adopted causality research design using panel data (2007 to 2015) of 16 commercial banks in Tanzania. The study employed Descriptive statistics and multiple regression analysis estimation methods. Likewise, Ordinary Least-Squares (OLS) regression technique was also used, and then Fixed Effects (FE) and Random Effects (RE) assumptions were considered.

The study found that occurrence of non-performing loans is negatively associated with the level of profitability in commercial banks in Tanzania. The results extend further the information asymmetry theory and bad management hypothesis. The findings of the study have both theoretical and managerial implications for practitioners and policy-makers
\end{abstract}

\section{Keywords: Non-performing loans, Credit risk, ROA, Profitability}

\section{Introduction}

The banking sector in Tanzania has fully grown to the level that it is currently dominating the financial sector. As at December 2016, the banking sector controlled over 20 trillion Tanzania shillings of financial assets, representing 70 percent of total financial assets, with loans and advances representing 50 percent of total banking financial assets. To ensure that commercial banks maintain good quality assets and operate within prudential requirements, the Bank of Tanzania (BOT) has increased on-site and offsite monitoring and passed Management of Risk Assets Regulations of 2014 (MRAR), and Credit Concentration and Other Exposure Limits Regulations of 2014 (CCOL). Despite all these efforts by the BOT, gross nonperforming loans have increased steadily from 4.4 percent in 2005 to 9.6 percent in 2016.

Increase in the level of gross non-performing loans pause a great risk to banks, the financial sector and the economy at large. Equally, failure to manage down non-performing loans over a long period gradually affects profitability of commercial banks

(Kaaya and Pastory, 2013). Consequently, nonerforming loans normally results in high loan provisioning which, leads to drop-in profits for many banks (Kithinji, 2010) and gradually minimizes the bank sector's ability to play its role in the development of the economy (Zaini et al, 2010).

The objective of this paper is to examine the impact of non-performing loans on the profitability of commercial banks in Tanzania. This paper will review literature on the impact of NPL on profitability in Tanzania and other countries. The main question this paper is trying to answer is, what is the impact of non-performing loan on the profitability of commercial bank in Tanzania? To respond to that question, this paper is organized into six sections. Section one introduces the topic on Bank Profitability, section two discusses review of literature on profitability, section three highlights the research methodology employed, section four 
discuss the findings of the research, section five provide recommendations and section six provide the conclusion of the research.

\section{Literature Review}

\section{A. Overview of the Banking Sector}

As at 31 December 2015, the Tanzania banking sector had 56 banking institutions consisting of 36 commercial banks, 12 community banks, 3 financial institutions, 2 development financial institutions and 3 deposit-taking microfinance banks. Out of 56 banking institutions, 7 are state-owned and 49 are privately owned banking institutions, of which 27 were locally owned, while 29 were foreign-owned banking institutions. The banking sector dominates the financial landscape and accounts for about 70 percent of the total financial assets evidenced by the growth of Loan advances and overdrafts to over Tzs 14.9 trillion in 2015 from Tzs 1 trillion in 2004.

\section{B. Theoretical Literature Review and Hypothesis Development}

Historically, the incidence of banking sector failure resulting from insolvency has often been associated with massive accumulation of non-performing loans (Fofack, 2005). Equally, failure to effectively reduce levels of non-performing loans may lead to bank failure (Richard et al., 2008). Samir and Kamra (2013) argue that non-performing loans have a deleterious impact on bank profits as they reduce interest income, and erode current profits and capital base through provisions. Non-performing loans accounted for about 75 percent of the total loan portfolios of over 60 banks that collapsed during the 1997 financial crisis in Indonesia (Caprio and Klingebiel, 1999).

Non-performing loans are considered determinants of profitability because, high levels of nonperforming loans adversely affect bank net profit through provisioning of doubtful debts and writeoffs of bad debts; which normally affect profitability and capital levels (Ombaba, 2013). Subsequently, the moment non-performing loans exceed bank capital in a relatively large number of banks can compound into a bank crisis, which eventually turns into a financial crisis (Biabani et al., 2012; Karim et al., 2010). Empirical studies (Kithinji, 2010, Ombaba, 2013) found a possible relationship between high levels of non-performing loans and low profitability. The theoretical perspectives that informed this research and the development of the hypotheses used to analyse the relationship between NPL and Profitability are information asymmetry theory and bad management hypothesis.
Information Asymmetry Theory argues that asymmetric information occurs when one party in a transactional relationship is more informed about the transaction than the other party. In the financial decision space, asymmetric information literature looks at the impact of decisions based on the difference in the information available to both parties (Mishkin, 1992). Lenders offering credit facilities to borrower's face uncertainty of loan repayment, as they cannot observe the characteristics and actions of the borrower, thus making it difficult to assess the creditworthiness of the borrower (Ariccia, 1998). Consequently, adverse selection leads to whereby high-quality borrowers are displaced by low-quality borrowers, which in the long run cause deterioration in the overall quality of bank loan portfolios and lead to accumulation of non-performing loans, decrease in profitability and erosion of capital (Bofondi and Gobbi, 2003; Bofondi and Ropele, 2011; Makri et al., 2014;).

Bad management hypothesis, first introduced by Berger and De Young (1997), points out that in responding to the increase in non-performing loans resulting from adverse selection, bank management tends to inject more resources into managing and monitoring bad loans, which in the long run results into the increase in the operating expenses over the increase in interest income, resulting to higher costto-income ratio. Accordingly, higher cost-to-income ratio is a sign of weak bank management, in underwriting, monitoring, and control of the loan portfolio (Louzis et al., 2010; Vardar and Özgüler, 2015; Muratbek, 2017). Therefore, we expect a negative relationship between non-performing loans and ROA (as a proxy for profitability). On this premise, it is therefore hypothesized that:

H1: The higher the non-performing loans, the lower the ROA of banks.

\section{Empirical Literature Review}

Several scholars (Prakash and Poudel, 2012; Roman and Tomuleasa, 2013; Samuel et al. 2012; Kithinji, 2010) who have examined the impact of credit risk management on the financial performance of banks have come up with mixed conclusions. Poudel (2012) study on the impact of default rates and cost per loan on banks' performance in Nepal concluded that credit risk management measured by default rate is crucial for bank performance, as it significantly contributes to bank profitability. Likewise, Roman and Tomuleasa (2013) study (2003 to 2011) on the impact of internal and external factors on the profitability of banks in EU countries, revealed that the increase in non-performing loans had a negative 
impact on banks' profitability. Kargi (2011) study (2004 to 2008) on the relationship between credit risk and profitability of Nigerian commercial banks revealed a negative relationship between credit risk and the profitability of commercial banks in Nigeria. Similarly, Kolapo et al. (2012) study on the impact of credit risk on commercial banks' profitability in Nigeria concluded that the increase in nonperforming loans reduces the banks' profitability.

The Karim et al. (2010) study on the relationship between non-performing loans and bank efficiency in Malaysia and Singapore revealed that a higher incidence of non-performing loans reduces banks' cost efficiency, thus negatively affecting profitability. Karim et al. (2010) results support the bad management hypothesis proposed by Berger and DeYoung (1997), suggesting that poor management in the banking institutions results in poor quality loans, and therefore, contributes to the increase in the level of non-performing loans and decrease in profitability. Kaaya and Pastory (2013) study on the relationship between credit risk and bank performance as measured by return on asset found a negative correlation between credit risks and bank profitability. Similarly, Madishetti and Rwechungura (2013) who examined the impact of credit risk on Tanzanian commercial banks' profitability revealed that increase in non-performing loans reduces profitability of commercial banks in Tanzania.

To the contrary, the Samuel et al. (2012) study (2005 to 2009) on the relationship between commercial banks' profitability and credit risk in Ghana found that credit risk plays a minimal impact on profitability. Samuel et al. (2012) study supports the Kithinji (2010) study (2004 to 2008) on the impact of credit risk on the performance of Kenyan banks, which concluded that credit risk insignificantly affects banks' performance in Kenya.

\section{ReSearch Methodology}

This research used secondary data from audited financial statements of 16 licensed and registered commercial banks in Tanzania commercial banks that have been in existence and operating from 2007 to 2015 and various reports from the Bank of Tanzania. A sample of 16 out of a population of 36 banks was purposefully selected based on the availability of financial data and was categorized based on assets size, loans size, liabilities positions, capital, and earnings. The selected banks represent approximately 75 percent of all banks' assets size, loans size, liabilities positions, and capital and earnings, therefore making this sample sufficiently representative of the population
This research adopted causality research design and deductive research strategy. The causality research design has been chosen because: i) the study attempted to test and analyse the relationship among hypothesized variables, ii) the design helps to find empirical association between the independent variables and a dependent variable.

This research used descriptive analysis and multiple regression analysis methods to analyze data. To ensure that the sample conform to multiple regression analysis methods, the data was tested for normality, linearity, multicollinearity, and heteroscedasticity. No significant violations were found.

\subsection{Measurement of Variables}

Dependent Variable for this research is Return on asset (ROA); it is calculated by dividing net profits after tax to total assets at the end of the financial year. ROA is an indicator of performance and measures how the banks are profitable relative to their assets, meaning how management is efficient in utilizing the company assets to generate profit. On average, higher ROA indicates effective and efficient use of a firm's assets to generate profits. This study has extracted ROA from published annual financial statements of commercial banks.

\section{Independent Variable}

Non-Performing Loans (NPL) ratio, which is calculated by dividing non-performing loans to total loans and advances; it is used as an indicator of credit risk. The higher the NPL ratio, the poorer the credit quality and, therefore, the higher the risk that more loan loss will be charged against income.

\section{Control Variables}

Liquidity ratio ( $L Q D T)$ is calculated by dividing net loans to total deposits. It is a measure of bank liquidity position. The higher the loan balances relative to deposits, the lower the liquidity level.

Capital adequacy ratio (SLVT) is the ratio of capital to the sum of a risk-weighted bank's assets. This ratio measures the amount of a bank's capital relative to the amount of its risk-weighted credit exposure. In the context of this thesis, CAR is defined as the ratio of Shareholders Funds or equity to Total Assets.

Gross Domestic Product (GDP) is used to proxy the cyclical behaviour of economic activity for this thesis. A similar measure was used as a proxy in other studies (Athanasoglou et al., 2006 and Sufian, 2011) on the relationship between macroeconomic activities and bank profitability. Empirical studies 
(Demirguc-Kunt and Huizinga, 2000; Bikker and between cyclical movement and bank profitability. $\mathrm{Hu}, 2002$ ) have suggested a possible relationship

Table 1: Measurement of Variables Impacting ROA

\begin{tabular}{|c|c|c|c|}
\hline Variable & Measurement Definition & $\begin{array}{l}\text { Acron } \\
\text { ym }\end{array}$ & $\begin{array}{l}\text { Expected } \\
\text { Sign }\end{array}$ \\
\hline \multicolumn{4}{|c|}{ DEPENDENT VARIABLE } \\
\hline ROA & Net Profits/Assets, in \% & ROA & \\
\hline \multicolumn{4}{|c|}{ INDEPENDENT VARIABLE } \\
\hline NPL & $\begin{array}{l}\text { Non-performing loans and total gross } \\
\text { loans ratio, in } \%\end{array}$ & NPL & - \\
\hline \multicolumn{4}{|c|}{ CONTROL VARIABLES } \\
\hline Liquidity & Loan to Deposits ratio, in \% & LQDT & - \\
\hline Capital Adequacy & Shareholders' Funds/Total Assets & $\begin{array}{l}\text { SLVT } \\
\text { GDPG }\end{array}$ & + \\
\hline GDP & Year-on-year GDP growth rate & $\mathrm{R}$ & - \\
\hline
\end{tabular}

\subsection{Econometric methodology}

Based on the theoretical relationship among variables, multiple regression models were developed as per the objectives of the study. The study employed a modified version of the econometric model of Akhtar et al. (2011) and Kargi (2011). A regression model is estimated to examine the relationship between NPL and ROA. The model is expressed as:

$\mathrm{ROA}=\alpha+\beta 1 \mathrm{NPL}+\gamma 2 \mathrm{LQDT}+\gamma 3 \mathrm{SLVT}+$ $\gamma 4 \mathrm{GDPGR}+\mathrm{e}$------------ (1)

Whereas;

$$
\begin{aligned}
& \alpha=\text { Constant parameter/Intercept } \\
& \beta=\text { Coefficients of independent variables } \\
& \gamma=\text { Coefficients of control variables } \\
& \text { 'e' represents the unexplained residual }
\end{aligned}
$$

Where, NPL: Non-Performing Loan to Loans and Advances, LQDT: Loan to Deposit Ratio, SLVT: Shareholders Funds/Total Assets, GDPGR: GDP growth rate (Control variable)

This research used three panel estimation methods:

1) Pooled Regression Model (OLS), 2) Fixed Effects

(FE) Model, 3) Random Effects (RE) Model. OLS assumes that all subjects are homogeneous which discounts the heterogeneity (individuality or uniqueness) that might exist among different subjects under study in the regression model (Woodridge, 2010). The Fixed Effects (FE) model takes into account heterogeneity or individuality among cross-section units by letting each entity have its own intercept value that captures the differences across entities (Gujarati and Porter, 2009). On the other hand, Random effects (RE) Model is used on assumptions that the unobserved individual heterogeneity is uncorrelated with the independent variables included in the model. The RE estimator assumes that the intercept of an individual unit is a random component that is drawn from a larger population with a constant mean value. The Hausman test shows the Chi Square of 18.86 with the $\mathrm{p}$ value of 0.17 . Given this, the results and discussion have focused on the outcome provided by the Random Effects model.

\section{Results and Discussion of Findings}

\section{A. Descriptive Statistics}

As it can be seen from Table 2, the results show a low minimum ROA of -13 percent which is due to accumulated losses which increased significantly in 2014. The mean value of Return on Assets is 2 percent, whereas maximum is 5 percent. The mean value of NPL is 7 percent, which range widely from a low of 0.1 percent to a high of 36.5 percent. The average capital ratio (SLVT) of 12 percent is consistent with the BOT's minimum capital adequacy ratio of 12 percent. The mean value of Liquidity (LQDT) is 62 percent, which is within acceptable levels of below 80 percent. The mean GDP growth over the last eight years averaged 7 percent, with the highest growth of 8 percent in 2011, and the lowest growth of 5 percent in 2012 . The high growth during the year 2011 was a result of expansion in the construction, public administration, defence, and financial intermediation sectors. The descriptive results of variables impacting ROA is presented in Table 2 below. 
Table 2: Descriptive Statistics of Variables Impacting ROA

\begin{tabular}{lrrrrrrrr}
\hline Variable & Obvs & Mean & Median & Max & Min & $\begin{array}{r}\text { Std. } \\
\text { Dev. }\end{array}$ & Skewness & Kurtosis \\
\hline ROA & 128 & 0.02 & 0.02 & 0.05 & $(0.13)$ & 0.02 & $(3.17)$ & 23.05 \\
NPL & 128 & 0.07 & 0.05 & 0.36 & 0 & 0.07 & 2.31 & 8.77 \\
SLVT & 128 & 0.12 & 0.12 & 0.24 & 0.06 & 0.03 & 1.04 & 5.30 \\
LQDT & 128 & 0.62 & 0.64 & 0.16 & 0.20 & 1.06 & $(0.51)$ & 3.39 \\
GDPGR & 128 & 0.06 & 0.07 & 0.08 & 0.05 & 0.01 & -0.05 & 1.66 \\
\hline
\end{tabular}

Source: Researcher's own construct using Tanzanian bank and macroeconomic data from 2007-2015.

\section{A. Correlation Results}

Pearson $r$ was calculated to determine whether a statistically significant correlation was present between non-performing loans, capital adequacy ratio, liquidity, and GDP growth rate with return on assets. The findings indicated that capital adequacy ratio and NPLs are significantly correlated with ROA, while GDP and Liquidity ratio are not correlated with ROA. The correlation matrix of dependent and independent variables shows that NPL is negative and significantly correlated with ROA. The results show that capital adequacy ratio (SLVT) is positive and significantly correlated with ROA, while it is insignificantly correlated with GDP and liquidity ratio. The correlation matrix table of variables impacting ROA is presented in Table 3 below.

Table 3: Correlation of Variables Impacting ROA

\begin{tabular}{l|lllll}
\hline & ROA & NPL & SLVT & LQDT & GDP \\
\hline ROA & 1 & & & & \\
NPL & $-0.6419^{*}$ & 1 & & & \\
SLVT & $0.2080^{*}$ & -0.1138 & 1 & & \\
LQDT & -0.1379 & -0.093 & -0.1384 & 1 & 1 \\
GDP & -0.044 & 0.0034 & 0.0677 & 0.0907 & 1 \\
\hline
\end{tabular}

Source: Researcher's own construct using Tanzanian bank and macroeconomic data from 2007-2015.

*Significant at $5 \%$ level, **significant at $10 \%$ level

\section{A. Regression Results}

The coefficient estimate of $N P L$ is negative and statistically significant, indicating that the higher the level of non-performing loans, the lower the ROA. The possible explanation for this relationship is that customer default on interest and principal payments affects both the balance sheet and income statement. Customer failure to repay principal amounts decreases the asset base of banks, the principal amount is written off as expenses on income statement, hence reduces bank profit. Similarly, customer failure to pay interest on loans as expected reduces bank income, which also decreases the level of profits to the bank. This finding supports information asymmetry theory and bad management hypothesis which argue that increase in NPL is a result of adverse selection, and is linked to management inability to control operating efficiency which in the long run lead to decrease in profitability. Therefore, the results support
Hypothesis 1 that states; the higher the nonperforming loans, the lower the ROA. The results are

consistent with the findings of Kithinji (2010) and Kargi (2011), Kolapo et al. (2012), Muhammad et al (2012), Samuel et al. (2012), and Madishetti, and Rwechungura (2013).

The estimated coefficient of Liquidity (LQDT) ratio is negative and statistically significant. The results indicate, as the loan to deposit ratio increases, the profit level of the bank decreases, implying that the bank is increasingly exposing itself to liquidity risk and financial distress when the liquidity ratio increases. A higher ratio gives the impression that the bank has reached its limit of funding loans from its own deposits, and uses more expensive methods such as expensive deposits, debt and equity financing to fund its loan book. This in turn reduces its profitability levels. These results are in line with the findings of Kithinji (2010), Kargi (2011), and Kolapo et al. (2012). 
The estimated coefficient of Capital Adequacy Ratio $(S L V T)$ is positive and statistically significant. The results indicate an increase in capital adequacy ratio has an explanatory power over the upward movement of bank profits. A possible explanation for this is that banks with higher capital ratio, depend on their own capital to fund asset growth. This reduces dependency on expensive external funding capital, and therefore leads to higher profitability.
These findings support the findings of Berger (1995), Vong and Chan (2006) and Ozili (2015).

The coefficient of GDP is negative and statistically insignificant, indicating an increase in GDP is associated with the decrease in ROA (a proxy for bank profitability) but GDP does not have explanatory power over bank profitability levels. A possible explanation for this is that an increase in economic activities is associated with a low rate of defaults.

Table 5: Regression Results on Variables Impacting ROA

\begin{tabular}{|l|c|c|c|}
\hline \multirow{3}{*}{ Independent Variables } & \multicolumn{2}{|l|}{ Dependent variable } \\
\cline { 2 - 4 } & Pooled OLS & Fixed Effects (FE) & Random Effects (RE) \\
\cline { 2 - 4 } & Coefficients & Coefficients & Coefficients \\
\cline { 2 - 4 } NPL & $-0.191^{* *}$ & $-0.147^{* *}$ & $-0.171^{* *}$ \\
\hline \multirow{2}{*}{ LQDT } & $(-9.656)$ & $(-5.225)$ & $(-7.430)$ \\
\cline { 2 - 4 } & $-0.023^{*}$ & $-0.005^{*}$ & $-0.015^{*}$ \\
\hline \multirow{2}{*}{ SLVT } & $(-2.661)$ & $(-0.357)$ & $(-1.511)$ \\
\hline \multirow{2}{*}{ GDP } & $0.080^{* *}$ & $0.095^{* * *}$ & $0.098^{* *}$ \\
\hline R-squared & $(1.659)$ & $(1.431)$ & $(1.816)$ \\
\hline Adjusted R-squared & -0.071 & -0.103 & -0.086 \\
\hline S.E. of regression & $(-0.497)$ & $(-0.798)$ & $0.674)$ \\
\hline F-statistic & 0.464 & 0.622 & 0.313 \\
\hline
\end{tabular}

Source: Researcher's own construct using Tanzanian bank data and macroeconomic data from 2007-2015. Note: Significant levels are reported with $*$, **and $* * *$ corresponding to $1 \%, 5 \%$ and $10 \%$ significant values. t-statistics are reported in parenthesis

Table 6: Summary of Results and Hypothesis Test of Impact of NPL on ROA

\begin{tabular}{|c|c|c|c|c|c|c|c|}
\hline $\begin{array}{l}\text { Hypothesis } \\
\text { Variable }\end{array}$ & ROA & & & & & & \\
\hline $\begin{array}{c}\text { Independent } \\
\text { Variables }\end{array}$ & $\begin{array}{l}\text { Hypothesi } \\
\text { s number }\end{array}$ & $\begin{array}{l}\text { Theory or } \\
\text { Hypothesis }\end{array}$ & $\begin{array}{l}\text { Hypothesis } \\
\text { sign }\end{array}$ & $\begin{array}{l}\text { Actua } \\
1 \text { sign } \\
\text { of } \\
\text { result }\end{array}$ & $\begin{array}{c}\mathrm{P} \\
\text { Value }\end{array}$ & $\begin{array}{l}\text { Statistical } \\
\text { significanc } \\
\text { e of results }\end{array}$ & $\begin{array}{c}\text { Conclusio } \\
\mathrm{n} \\
\text { (Hypothesi } \\
\text { s) } \\
\end{array}$ \\
\hline \multicolumn{8}{|c|}{ BANK SPECIFIC } \\
\hline NPL & 1 & $\begin{array}{l}\text { Information } \\
\text { Asymmetry/ } \\
\text { Adverse } \\
\text { selection }\end{array}$ & - & - & 0.00 & Significant & Supported \\
\hline
\end{tabular}

\section{Conclusion}

In this study, we used panel data methods to examine impact of NPL on bank profitability. The study found that an increase in non-performing loans is associated with a decrease in ROA. These results support information asymmetry theory and bad management hypothesis, which argue, increased 
exposure to credit risk measured by NPLs is normally associated with an increase in operating costs and lead to decreased profitability.

The results of this study leave several implications for researchers, practitioners and regulators.

For practitioners, bank managers need to thoroughly scrutinize client data and information during the credit analysis stage so to reduce information asymmetry. Equally, management need to invest in robust credit information systems; thus, to reduce informational gaps and increase access to complete, accurate and reliable information concerning borrowers. Furthermore, bank management need to employ cost efficiency mechanisms in managing their loan portfolio.

Regulators on the other hand, need to closely monitor bank operating efficiency ratios and capital adequacy by paying more attention to cost-to-income ratio trends and bank's capital position. Specifically, regulators should devise regulations and monitoring tools that will trigger early warning signals of potential bank failures due to accumulation of NPL.

\section{REFERENCES}

1. Akhtar, F. M., Ali, K., and Sadaqat, S. (2011). Factors Influencing the Profitability of Conventional Banks of Pakistan. International Research Journal of Finance and Economics, ISSN 1450-2887 Issue 66 (2011).

2. Ariccia, G. D. (1998). Asymmetric Information and the Market Structure of Banking Industry, IMF Working Papers WP/98/92, International Monetary Fund, Research Department.

3. Berger, A. (1995). The Relationship between Capital and Earnings in Banking. Journal of Money, Credit and Banking, Vol. 27, No. 2, pp. 432-456.

4. Berger, N., A and De Young, R. (1997). Problem Loans and Cost Efficiency in Commercial Banks, Washington DC. Journal of Banking and Finance, Vol. 21, 1997.

5. Biabani, S., Gilaninia, S., and Mohabatkhah, H. (2012). Assessment of Effective Factors on Non-Performing Loans (NPLs) Creation: Empirical Evidence from Iran (2006-2011). Journal of Basic and Applied Scientific Research, ISSN 2090-4304, 2(10)1058910597, 2012.

6. Bikker, J. and H. Hu (2002). Cyclical patterns in profits, provisioning and lending of banks and procyclicality of the new Basel capital requirements. BNL Quarterly Review 221, 143-175.

7. Bofondi, M. and Gobbi, G. (2003). Bad Loans and Entry in Local Credit Markets. Bank of Italy Research Department, Rome.

8. Bofondi, M. and Ropele, T. (2011). Macroeconomic determinants of bad loans: evidence from Italian banks. Occasional Papers, 89.

9. Caprio, G., and Klingebiel, D. (1996). Bank Insolvency: Bad Luck, Bad Policy or Bad Banking, Annual World Bank Conference on Development Economics.

10. Caprio, Gerard, and Daniela Klingebiel. (1999). "Episodes of Systematic and Borderline Financial Crises." World Bank, mimeo.

11. DermirgucKunt, A., and Huizinga, H., (2000). Financial structure and bank profitability. World Bank working paper no. 2430.

12. Fofack, H. (2005). Non-Performing Loans in Sub-Saharan Africa: Causal Analysis and Macroeconomic Implications, World Bank Policy Research Working Paper No. WP 3769.

13. Gujarati, D. N., and Porter, D. (2009). Basic Econometrics Mc Graw-Hill International Edition.

14. Kaaya, A. and Pastory, D (2013). Credit Risk and Commercial Banks Performance in Tanzania: a Panel Data Analysis. Research Journal of Finance and Accounting. ISSN 2222-1697 (Paper) ISSN 2222-2847, Vol.4, No.16 2013.

15. Kargi, H.S. (2011). Credit Risk and the Performance of Nigerian Banks, AhmaduBello University, Zaria.

16. Karim, M. Z. A., Chan, C. S., and Hassan, S. (2010). Bank Efficiency and Non-Performing Loans: Evidence from Malaysia and Singapore. Prague Economic Papers, 2, 2010.

17. Kolapo, T., Ayeni, R., and Oke, M. (2012). Credit Risk and Commercial Banks' Performance in Nigeria: A Panel Model Approach. Australian Journal of Business and Management Research, Vol. 2 No. 0228.

18. Kithinji, A. (2010). Credit Risk Management and Profitability of Commercial Banks in Kenya, Business School, University of Nairobi. 
19. Louzis, D. P., Vouldis, A.T., and Metaxas, V.L. (2010). Macroeconomic and Bankspecific Determinants of Nonperforming Loans in Greece: A Comparative Study of Mortgage, Business, and Consumer Loan Portfolios., Bank of Greece Working Paper 118.

20. Madishetti, S., \& Rwechungura, K. A. (2013). Determinants of bank profitability in a developing economy: empirical evidence from Tanzania. Asian Journal of Research in Banking and Finance, 3(11), 46.

21. Makri, V., Tsagkanos, A., and Bellas, A. (2014). Determinants of non-performing loans: The case of Eurozone. Panoeconomicus, 61(2), 193.

22. Mishkin, F.S. (1992) "Anatomy of a financial crisis" Journal of Evolutionary Economics June 1992, Volume 2, Issue 2, pp 115-130

23. Muratbek, D. (2017). Determinants Of NonPerforming Loans in Kazakhstan (Doctoral Dissertation, Nazarbayev University, School Of Humanities And Social Sciences.).

24. Makri, V., Tsagkanos, A., and Bellas, A. (2014). Determinants of non-performing loans: The case of Eurozone. Panoeconomicus, 61(2), 193.

25. Muhammad, N., Shahid, M., and Shahid, A,. (2012). Credit Risk and the Performance of Nigerian Banks. Interdiplinaly Journal of Contemporary Research in Business. Vol. 4, No. 731.

26. Ozili, P. K. (2015). Determinants of Bank Profitability and Basel Capital Regulation: Empirical Evidence from Nigeria. Research Journal of Accounting and Finance, 6(2), 124-131.

27. Ombaba, M. K. (2013). Assessing the Factors Contributing to Non-Performance Loans in Kenyan Banks. European Journal of Business and Management, 5(32), 155-162

28. Poudel, R. P. S. (2012). The impact of credit risk management on financial performance of commercial banks in Nepal, International Journal of Arts and Commerce Vol. 1 No. 5 October 2012.

29. Richard, E., Chijoriga, M., Kaijage, E., Peterson, C., and Bohman, H. (2008). Credit risk management system of a commercial bank in Tanzania. International Journal of Emerging Markets, Vol. 3 Iss: 3, pp.323 332.
30. Roman, A., and Tomuleasa, I. I. (2013). Analysis of Profitability Determinants: Empirical Evidence of Commercial Banks in the New EU Member States

31. Samuel, H., Julius, D. and Samuel, K. (2012). Credit Risk and Profitability of Selected Banks in Ghana. Research Journal of Finance and Accounting. Vol. 3, No7. 2012

32. Sufian, F. (2011). Profitability of the Korean banking sector: Panel evidence on bankspecific and macroeconomic determinants. Journal of Economics and Management, 7(1), 43-72.

33. Vardar, G., and Özgüler, I. C. (2015). Short Term and Long Term Linkages among Nonperforming Loans, Macroeconomic and Bank-Specific Factors: An Empirical Analysis for Turkey/Takipteki Krediler, Makroekonomik ve Banka Özellikli Faktörler Arasindaki Uzun ve Kisa Dönemli Iliskiler: Türkiye için Ampirik bir Analiz. Ege Akademik Bakis, 15(3), 313.

34. Vong, P.I., and Chan H. S. (2006). Determinants of Bank Profitability in Macao. Conference proceedings of the 30th Anniversary of Journal of Banking and Finance Conference, Beijing.

35. Wooldridge, J. M. (2010). Econometric Analysis of Cross Section and Panel Data. MIT Press.

36. Zaini, M., Karim, A., Chan, S., and Hassan, S. (2010). Bank Efficiency and NonPerforming Loans: Evidence from Malaysia and Singapore, Prague Economic Papers. 